\title{
PENGARUH KOMUNIKASI INTERPERSONAL DAN MOTIVASI KERJA TERHADAP KINERJA GURU SMA NEGERI SE KOTA PEKANBARU
}

\author{
Elfira Oktarina 1) \\ Makhdalena ${ }^{2)}$ \\ Caska ${ }^{3)}$ \\ 1) Post Graduate Student of Riau University \\ 2) Lecturer of Education Management Study Programme PPs University of Riau \\ ${ }^{3)}$ Lecturer of Education Management Study Programme PPs University of Riau
}

\begin{abstract}
The purposes of this research was to studied and analyzed the effect of interpersonal communication and work motivation either simultaneously or partially on Teacher Performance at Senior High School (SMA) in Pekanbaru City. The population of this study was 1027 Teachers. The Sample size of this study used the formula Taro Yamane totaly 288 Teachers. The sampling technique used simple random sampling. The type of data in this study is primary data sourced from Teachers Senior High Scholl in Pekanbaru. Data collection techniques using a questionnaire. Data analysis techniques using Multiple Regression with the help of SPSS. The results showed that Interpersonal Communication and Work Motivation had a positive and significant effect on Teacher Performance either simultaneously or partially
\end{abstract}

Keywords: Interpersonal Communication, Work Motivation, Teacher Performance

\begin{abstract}
ABSTRAK
Tujuan dari penelitian ini adalah untuk mengetahui dan menganalisis pengaruh komunikasi interpersonal dan motivasi kerja Guru baik secara simultan maupun secara parsial terhadap Kinerja Guru SMA Negeri se Kota Pekanbaru. Populasi dari Penelitian ini berjumlah 1027 guru. Ukuran Sampel dalam penelitian ini menggunakan rumus Taro Yamane yang berjumlah 288 Guru. Teknik Penarikan sampel menggunakan Simple random Sampling. Jenis data dalam penelitian ini adalah data primer yang bersumber dari guru SMA Negeri Kota Pekanbaru. Teknik Pengumpulan data menggunakan kuesioner. Teknik analisis data menggunakan Regresi Berganda dengan bantuan SPSS. Hasil penelitian menunjukkan bahwa Komunikasi Interpersonal dan Motivasi Kerja berpengaruh positif dan signifikan terhadap Kinerja Guru baik secara simultan maupun secara parsial.
\end{abstract}

Kata Kunci : Komunikasi Interpersonal, Motivasi Kerja, Kinerja Guru 


\section{PENDAHULUAN}

Kinerja Guru merupakan komponen sumber daya manusia yang harus dibina dan dikembangkan terus menerus agar dapat melakukan fungsinya secara profesional sehingga dapat mempersiapkan generasi yang tidak saja memiliki keterampilan dan keahlian dibidangnya masing - masing tetapi berakhlak mulia sebagai manusia seutuhnya. Untuk mencapai tujuan yang diinginkan maka diperlukan kinerja guru yang optimal. Kinerja merupakan suatu kegiatan yang dilakukan untuk melaksanakan, menyelesaikan tugas dan tanggung jawab sesuai dengan harapan dan tujuan yang telah ditetapkan (Supardi : 2014).

Kinerja sering disebut dengan prestasi yang merupakan hasil atau apa yang keluar (outcomes) dari sebuah pekerjaan dan kontribusi sumber daya manusia terhadap organisasi. Guru merupakan pihak yang paling banyak bersentuhan langsung dengan siswa dalam proses pendidikan/pembelajaran di sekolah. Kinerja seorang guru dikatakan baik jika guru telah melakukan unsur-unsur yang terdiri dari kesetiaan dan komitmen yang tinggi pada tugas mengajar, menguasai dan mengembangkan bahan pelajaran, kedisiplinan dalam mengajar dan tugas lainnya, kreativitas dalam pelaksanaan pengajaran, kerjasama dengan semua warga sekolah, kepemimpinan yang menjadi panutan siswa, kepribadian yang baik, jujur, dan objektif dalam membimbing siswa, serta tanggung jawab terhadap tugasnya

Berdasarkan hasil observasi dan wawancara dengan beberapa wakil kepala sekolah di SMA Negeri Kota Pekanbaru dapat disimpulkan fenomena - fenomena sebagai berikut: (1) masalah internal yang muncul seperti adanya ketidakcocokan pemikiran dalam perencanaan tujuan sekolah. (2) Masih kurangnya keterbukaan dan keharmonisan antara guru dan guru, hal tersebut tentu saja dapat mengganggu kinerja guru. (3) Masih rendahnya kesediaan guru bekerjasama dengan guru lain maupun dengan pimpinan dalam melaksanakan tugas. (4) Masih ada beberapa guru yang sering izin tanpa alasan yang jelas, serta pada saat bel sudah berbunyi terlambat untuk masuk kedalam kelas, baik pada saat awal jam pelajaran maupun saat pertukaran jam pelajaran. (5) Masih ada beberapa guru yang terkesan membosankan dan beberapa siswa tidak semangat ketika menerima pelajaran tersebut dikarenakan belum maksimal menggunakan media pembelajaran dalam proses pembelajaran. (6) Masih ada beberapa guru yang nilai UKG nya rendah.

Menurut Rofijah (2017); Fitri Afrianti (2015); Aleksius Madu (2017); Alice Tjandralila (2004) Kinerja Guru dipengaruhi oleh Komunikasi Interpersonal dan Motivasi Kerja.

\section{Rumusan Masalah}

Rumusan Masalah dalam Penelitian ini adalah "Apakah komunikasi interpersonal dan motivasi kerja guru berpengaruh secara simultan maupun parsial terhadap kinerja guru di SMA Negeri se Kotamadya Pekanbaru?"

\section{Tujuan Penelitian}

Penelitian ini bertujuan untuk mengetahui dan menganalisis pengaruh komunikasi interpersonal dan motivasi kerja baik secara simultan maupun secara parsial berpengaruh terhadap kinerja guru di SMA Negeri se Kotamadya Pekanbaru

\section{Manfaat Penelitian}

a. Manfaat yang dapat diambil dari penelitian ini diantaranya dijadikan referensi bagi kepala sekolah dan dinas pendidikan guna meningkatkan semangat kerja guru SMA Negeri se kota Pekanbaru

b. Sebagai bahan kajian untuk mengembangkan pengetahuan tentang pengaruh Komunikasi Interpersonal dan motivasi kerja terhadap kinerja Guru di SMA Negeri Se - Kota Pekanbaru

\section{TINJAUAN PUSTAKA}

\section{Kinerja Guru}




\section{a. Pengertian Kinerja Guru}

Kinerja adalah hasil yang dicapai oleh seseorang menurut ukuran yang berlaku untuk pekerjaan yang bersangkutan (Pandi Affandi, 2018 : 84).

Kinerja (prestasi kerja) adalah hasil kerja secara kualitas dan kuantitas yang dicapai oleh seorang pegawai dalam melaksanakan tugasnya sesuai dengan tanggung jawab yang diberikan ( Hesti Murwati, 2013).

Menurut Mangkunegara (2013:67) istilah kinerja berasal dari kata Job Performance atau actual Performance yakni prestasi kerja atau kinerja sesungguhnya dari seorang pegawai/karyawan, maka pengertian kinerja adalah hasil kerja secara kualitas dan kuantitas yang dicapai oleh seorang pegawai dalam melaksanakan tugasnya sesuai tanggungjawab yang diberikaan kepadanya. Sedangkan menurut Mulyadi (2015:63) mendefenisikan kinerja sebagai hasil kerja yang dicapai oleh pekerja atau karyawan secara kualitas maupun kuantitas yang sesuai dengan tugas dan tanggungjawab. Sedangkan menurut Wibowo (2013 : 7) kinerja adalah tentang melakukan pekerjaan dan hasil yang dicapai dari pekerjaan tersebut. Dan kinerja adalah tentang apa yang dikerjakan dan bagaimana cara mengerjakannya.

Berdasarkan pengertian-pengertian mengenai kinerja di atas, penulis berkesimpulan bahwa kinerja adalah hasil kerja baik secara kuantitas maupun kualitas dari apa yang dikerjakan berdasarkan standar yang telah ditetapkan dan bagaimana cara mengerjakannya.

Sedangkan pengertian guru dalam Undang - Undang Guru dan Dosen Nomor 14 tahun 2005 Pasal 8 dijelaskan bahwa maksud guru adalah pendidik professional dengan utama tugas mendidik, mengajar, membimbing, mengarahkan, melatih, menilai, dan mengevaluasi peserta didik pada pendididkan usia dini jalur pendidikan formal, pendidikan dasar, dan menengah.

Berdasarkan peraturan manteri pendidikan nasional nomor 35 tahun 2010 menjelaskan Kinerja guru adalah hasil penilaian terhadap proses dan hasil kerja yang dicapai guru dalam melaksanakan tugasnya.

Menurut Supardi (2014 : 54) Kinerja Guru Merupakan kemampuan seseorang guru dalam melaksanakan tugas pembelajaran di sekolahlmadrasah dan bertanggungjawab atas perserta didik di bawah bimbinganya dengan meningkatnya prestasi belajar perserta didik.

Berdasarkan beberapa pendapat para ahli tersebut, dapat disimpulkan bahwa kinerja guru adalah hasil kerja yang dicapai oleh seorang guru di lembaga pendidikan atau madrasah sesuai dengan tugas dan tanggung jawabnya dalam mencapai tujuan pendidikan.

\section{b. Indikator Kinerja Guru}

Untuk mengukur kinerja guru diperlukan sebuah alat pengukur kinerja guru. Saat ini pemerintah sedang menjalankan suatu program untuk meningkatkan kinerja dan mutu layanan pendidikan yaitu, dengan adanya Uji Kompetensi Guru (UKG). Menurut Mulyasa ( 2013:55) melalui UKG diharapkan diperoleh gambaran dan pemetaan terhadap kompetensi serta kinerja guru sebagai dasar untuk melakukan pembinaan agar guru dan tenaga kependidikan lainnya dapat memenuhi standar pelayanan minimal (SPM).

Sejalan dengan itu, Rakhman, dkk (2005 : 72) menyatakan bahwa, kinerja guru dapat dinilai dari aspek kemampuan dasar yang harus dimiliki oleh guru yang dikenal dengan kompetensi. Dalam UUGD 14/2005 pasal 8 dan Permendiknas No. 13 Tahun 2007 tentang standar Kinerja Kepala Sekolah mengatakan bahwa ada empat kompetensi yang harus dimiliki oleh guru, yaitu: (1) kompetensi pedagogic, (2) professional, (3) kepribadian dan (4) Kompetensi Sosial.

\section{c. Faktor - Faktor yang Mempengaruhi Kinerja Guru}

Indrafachrudi (2000:52) membagi faktor-faktor yang mempengaruhi kinerja 
kedalam dua kategori yakni: Faktor internal dan faktor eksternal. Faktor internal yaitu faktor yang berasal dari dalam diri seseorang yang dapat mempengaruhi kinerja seseorang dalam menjalankan pekerjaannya, antara lain; motivasi dan minat, bakat, watak, sifat, usia, jenis kelamin, pendidikan, dan pengalaman, sedangkan faktor eksternal yaitu faktor yang datang dari luar diri seseorang yang dapat mempengaruhi kinerjanya, antara lain; lingkungan fisik, sarana dan prasarana, imbalan, suasana, kebijakan dan sistem administrasi.

Menurut Rofijah (2017) Kinerja dipengaruhi oleh komunikasi Interpersonal.

\section{Komunikasi Interpersonal}

\section{a. Pengertian Interpersonal \\ Komunikasi}

Menurut Arni Muhammad (2014:4)

Komunikasi interpersonal adalah proses pertukaran informasi diantara seseorang dengan paling kurang seorang lainnya atau biasanya di antara dua orang yang dapat langsung diketahui balikannya.

Brent D. Ruben dalam Muhammad (2011:3) menjelaskan komunikasi manusia adalah suatu proses melalui mana individu dalam hubungannya, dalam kelompok, dalam organisasi dan dalam masyarakat menciptakan, megirimkan, dan menggunakan informasi untuk mengkoordinasi lingkungannya dan orang lain. Komunikasi interpersonal tidaklah bersifat statis, tapi selalu berubah. Untuk memelihara dan memperteguh hubungan interpersonal,perubahan memerlukan tindakan-tindakan tertentu untuk mengembalikan keseimbangan hubungan interpersonal. (Daryanto, 2016:101)

Komunikasi interpersonal erat kaitannya dengan kecerdasan interpersonal karena individu yang memiliki kecerdasan interpersonal banyak memiliki teman,dilihat dari penjelasan tersebut maka dapat diambil kesimpulan bahwa dari kecerdasan interpersonal akan tercipta hubungan interpersonal yang baik. (Suciati, 2015:183)
Jadi, dapat disimpulkan bahwa komunikasi Interpersonal adalah suatu proses kegiatan manusia yang terdiri dari dua orang atau lebih yang didalamnya ada suatu proses pengiriman pesan dari seseorang kepada orang lain dan merupakan interaksi antara pribadi-pribadi yang terlihat secara utuh dan langsung satu sama lain dalam menyampaikan dan menerima pesan nyata agar dapat menggugah partisipasi satu sama lain yang diukur.

\section{b. Indikator Interpersonal}

Adapun indikator komunikasi interpersonal adalah (1) Nyaman saat berkomunikasi; (2) Memastikan pesan diterima, (3) Menjadi pendengar yang baik; (4) Berkomunikasi langsung; (5) Memberi feedback; (6) Berkomitmen tindak lanjut.

\section{Motivasi Kerja}

\section{a. Pengertian Motivasi Kerja}

Hasibuan (2014:141) Motivasi adalah pemberian daya penggerak yang menciptakan kegairahan kerja seseorang agar mereka mau bekerja sama, efektif dan berintegrasidengan segala upayanya untuk mencapai kepuasan.

Menurut Sopiah (2013: 170) motivasi adalah keadaan dimana usaha dan kemauan keras seseorang diarahkan kepada pencapaian hasil-hasil atau tujuan tertentu. Hasil-hasil yang dimaksud bisa berupa produktifitas, kehadiran atau prilaku kerja dan kreatif lainnya.

Menurut Simamora dalam Siti Hiadayah (2011), menyatakan bahwa motivasi adalah dorongan psikologis yang mengarahkan seseorang menuju sebuah tujuan. Kata motivasi melibatkan lebih dari gerak fisik mental. Motivasi juga mempunyai dua sisi gerakan dan motif. Gerakan dapat dilihat akan tetapi motif harus disimpulkan. Motif sering didefinisikan sebagai kebutuhan, dorongan, keinginan atau impuls di dalam diri individu.

Dalam Oemar Hamalik (2009:158) Motivasi kerja mendorong timbulnya 
kelakuan dan mempengaruhi serta mengubah kelakuan, jadi fungsi motivasi kerja itu menurut Oemar Hamalik antara lain (1) mendorong timbulnya kelakuan atau suatu perbuatan, (2) motivasi berfungsi sebagai pengarah artinya mengarahkan perbuatan ketercapaian tujuan yang diinginkan, (3) motivasi berfungsi sebagai penggerak, dimana besar kecilnya motivasi akan menentukan cepat atau lambatnya suatu pekerjaan.

Berdasarkan uraian di atas dapat disimpulkan bahwa yang dimaksud motivasi kerja dalam penelitian ini adalah suatu dorongan dalam diri individu yang menggerakkan tingkah lakunya untuk melaksanakan sesuatu dan untuk mencapai tujuan tertentu yang berhubungan dengan lingkungan kerja, dimana dengan adanya motivasi kerja diharapkan setiap orang mau bekerja keras dan antusias sehingga yang kan dicapai itu dapat dikomunikasikan dengan baik dan terciptanya kinerja yang baik pula.

\section{b. Indikator Motivasi Kerja}

Adapun indikator Motivasi Kerja adalah (1)kebutuhan yang harus dipenuhi; (2) kepuasan dalam bekerja, pengakuan: (3) penghargaan/prestasi, (4) minat terhadap pekerjaan dan (5) tanggung jawab terhadap pekerjaan.

\section{Kerangka Berfikir}

\section{a. Pengaruh}

Komunikasi

Interpersonal Terhadap Kinerja

\section{Guru}

Menurut Arni Muhammad (2014:4)

Komunikasi interpersonal adalah proses pertukaran informasi diantara seseorang dengan paling kurang seorang lainnya atau biasanya di antara dua orang yang dapat langsung diketahui balikannya

Penelitian yang telah dilakukan oleh Rofijah (2017) mengemukakan bahwa Komunikasi Interpersonal kepala sekolah dan motivasi kerja secara bersama-sama berpengaruh terhadap kinerja guru. Hal serupa juga dikemukakan oleh, Fitrina Afrianti (2013) bahwa variabel motivasi kerja dan komunikasi interpersonal secara simultan berpengaruh signifikan terhadap kinerja guru pada SMA Negeri 6 Kerinci Kecamatan Danau Kerinci

Berdasarkan penjelasan di atas, dapat disimpulkan untuk mencapai tujuan yang diinginkan maka diperlukan kerjasama yang baik antara kepala sekolah dan guru, guru dengan guru ataupun guru dengan siswa. Salah satunya dengan proses komunikasi yang baik. Komunikasi yang terjadi di sekolah terutama antara kepala sekolah dan guru, jika dilakukan secara baik dan intensif, maka akan mempengaruhi sikap guru dalam menjalankan tugasnya sehari-hari, yang berujung pada peningkatan kinerjanya di sekolah. Oleh karena itu pentingnya komunikasi interpersonal yang efektif yang terjalin harmonis.

\section{b. Pengaruh Motivasi kerja Terhadap Kinerja Guru}

Menurut Simamora dalam Siti Hiadayah (2011), menyatakan bahwa motivasi adalah dorongan psikologis yang mengarahkan seseorang menuju sebuah tujuan. Kata motivasi melibatkan lebih dari gerak fisik mental. Motivasi juga mempunyai dua sisi gerakan dan motif. Gerakan dapat dilihat akan tetapi motif harus disimpulkan. Motif sering didefinisikan sebagai kebutuhan, dorongan, keinginan atau impuls di dalam diri individu.

Hal ini sesuai dalam Agus Budi harianto (2010) yang menerangkan bahwa motivasi kerja memiliki pengaruh yang positif dan signifikan terhadap kinerja pegawai di Dinas pendidikan Kabupaten Sukoharjo. Kemudian hasil penelitian Agus Budi Harianto mendukung hasil penelitian Mustamil (2008) bahwa motivasi berpengaruh positif terhadap kinerja pegawai di kantor Departemen Agama Kabupaten Boyolali.

Berdasarkan Keterangan diatas dapat disimpulkan bahwa motivasii berpengaruh terhadap kinerja. Karena Kinerja memberikan dampak yang serius bagi suatu organisasi terutama sekolah. Kinerja yang 
dirasakan oleh guru akan menimbulkan semangat untuk bekerja lebih baik. Seorang guru mempunyai tingkat kinerja yang tinggi apabila banyak aspek dalam pekerjaan yang sesuai dengan keinginannya.

Guru yang mempunyai motivasi kerja yang tinggii akan senantiasa bekerja keras untuk mengatasi segala jenis permasalahan yang dihadapi dengan harapan mencapai hasil yang lebih baik lagi. Pencapaian suatu tujuan tidak terlepas dari motivasi guru dalam bekerja, karena motivasi merupakan pendorong semangat dan kemauan untuk bekerja dalam mencapai keberhasilan kerja guru. Dengan adanya motivasii kerja yang dimiliki guru diduga akan meningkatkan kinerjanya. Dengan kata lain, seorang guru akan melakukan semua pekerjaannya dengan baik apabila ada faktor pendorong (motivasi).

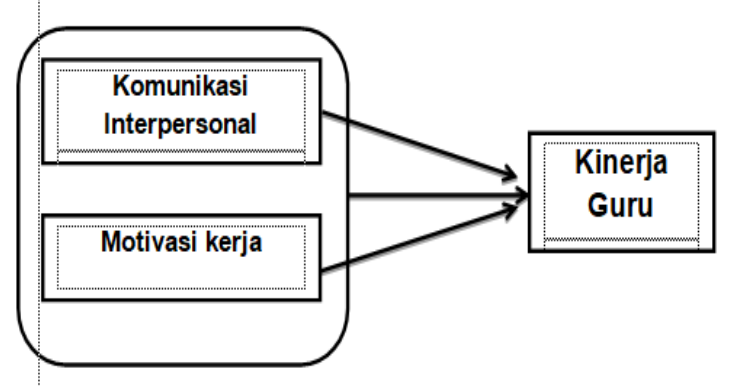

Gambar 1. Pengaruh Komunikasi Interpersonal dan Motivasi Kerja Terhadap Kinerja guru

Berdasarkan rumusan masalah dan tinjauan pustaka maka hipotesis penelitian ini adalah: Komunikasi interpersonal dan motivasi kerja guru berpengaruh secara simultan maupun parsial terhadap Kinerja Guru.

\section{METODOLOGI PENELITIAN}

Objek dari Penelitian ini adalah Komunikasi Interpersonal (X1), Motivasi Kerja (X2) dan Kinerja Guru (Y).

Populasi dari Penelitian ini adalah Guru SMA Negeri Se Kota Pekanbaru yang berjumlah 1027 Guru. Ukuran sampel menggunakan Rumus Taro Yamane yang berjumlah 288 Guru. Teknik penarikan sampel dengan Simple Random Sampling.

Jenis data adalah data primer yang bersumber dari guru. Teknik Pengumpulan data menggunakan kuesioner. Teknik analisis data menggunakan Regresi Berganda dengan bantuan SPSS.

\section{Operasionaliasi Variabel Penelitian}

Tabel 1. Matrik Operasionalisasi Variabel Penelitian

\begin{tabular}{|c|c|c|c|}
\hline Variabel & Konsep & Indikator & Skala \\
\hline 1 & 2 & 3 & 4 \\
\hline \multirow{4}{*}{$\begin{array}{l}\text { Kinerja Guru } \\
\text { (Y) }\end{array}$} & \multirow{4}{*}{$\begin{array}{l}\text { Kinerja sebagai hasil kerja } \\
\text { yang dicapai oleh pekerja } \\
\text { atau karyawan secara kualitas } \\
\text { maupun kuantitas yang sesuai } \\
\text { dengan tugas } \\
\text { tanggungjawab dan } \\
(2015: 63)\end{array}$} & Kompetensi Pedagogik & \multirow{4}{*}{ Rasio } \\
\hline & & Kompetensi Sosial & \\
\hline & & Kompetensi Kepribadian & \\
\hline & & Kompetensi Keterampilan & \\
\hline \multirow{3}{*}{$\begin{array}{l}\text { Komunikasi } \\
\text { Interpersonal } \\
\text { (X1) }\end{array}$} & \multirow{3}{*}{$\begin{array}{l}\text { Komunikasi interpersonal } \\
\text { adalah proses pertukaran } \\
\text { informasi diantara seseorang } \\
\text { dengan paling kurang seorang } \\
\text { lainnya atau biasanya di }\end{array}$} & $\begin{array}{l}\text { Nyaman saat } \\
\text { berkomunikasi }\end{array}$ & \multirow{3}{*}{ Ordinal } \\
\hline & & $\begin{array}{l}\text { Memastikan pesan } \\
\text { diterima }\end{array}$ & \\
\hline & & $\begin{array}{l}\text { Menjadi pendengar yang } \\
\text { aktif }\end{array}$ & \\
\hline
\end{tabular}




\begin{tabular}{|c|c|c|c|}
\hline & \multirow{3}{*}{$\begin{array}{l}\text { antara dua orang yang dapat } \\
\text { langsung diketahui } \\
\text { balikannya. Arni Muhammad } \\
(2014: 4)\end{array}$} & Berkomunikasi langsung & \\
\hline & & Memberifeedback & \\
\hline & & Berkomitmen tindak lanjut & \\
\hline \multirow{6}{*}{$\begin{array}{c}\text { Motivasi } \\
\text { Kerja (X2) }\end{array}$} & \multirow{6}{*}{$\begin{array}{l}\text { Motivasi adalah dorongan } \\
\text { psikologis yang mengarahkan } \\
\text { seseorang menuju sebuah } \\
\text { tujuan. Kata motivasi } \\
\text { melibatkan lebih dari gerak } \\
\text { fisik mental. Motivasi juga } \\
\text { mempunyai dua sisi gerakan } \\
\text { dan motif. Gerakan dapat } \\
\text { dilihat akan tetapi motif harus } \\
\text { disimpulkan. Motif sering } \\
\text { didefinisikan sebagai } \\
\text { kebutuhan, dorongan, } \\
\text { keinginan atau impuls di } \\
\text { dalam diri individu. Menurut } \\
\text { Simamora dalam Siti } \\
\text { Hiadavah (2011). }\end{array}$} & $\begin{array}{l}\text { Kebutuhan yang harus } \\
\text { dipenuhi }\end{array}$ & \multirow{6}{*}{ Ordinal } \\
\hline & & Kepuasan dalam bekerja & \\
\hline & & Pengakuan & \\
\hline & & Penghargaan/Prestasi & \\
\hline & & Minat Terhadap pekerjaan & \\
\hline & & $\begin{array}{l}\text { Tanggung jawab terhadap } \\
\text { Pekerjaan }\end{array}$ & \\
\hline
\end{tabular}

\section{HASIL PENELITIAN DAN PEMBAHASAN}

\section{Deskriptif Variabel Penelitian}

Tabel 2. Deskriptif Analisis

\begin{tabular}{|c|c|c|c|c|c|c|c|}
\hline No & Keterangan & Mean & Min & Max & $\begin{array}{c}\text { Above } \\
\text { Mean }\end{array}$ & $\begin{array}{c}\text { Below } \\
\text { Mean }\end{array}$ & $\begin{array}{c}\text { STd. } \\
\text { Deviation }\end{array}$ \\
\hline 1 & Kinerja Guru & 62.44 & 20 & 99 & $51.4 \%$ & $48 \%$ & 17.403 \\
\hline 2 & $\begin{array}{c}\text { Komunikasi } \\
\text { Interpersonal }\end{array}$ & 45.35 & 15 & 60 & $59.7 \%$ & $40.2 \%$ & 11.460 \\
\hline 3 & Motivasi Kerja Guru & 45.95 & 15 & 60 & $57 \%$ & $42 \%$ & 11.313 \\
\hline
\end{tabular}

\section{Hasil Uji Hipotesis Penelitian}

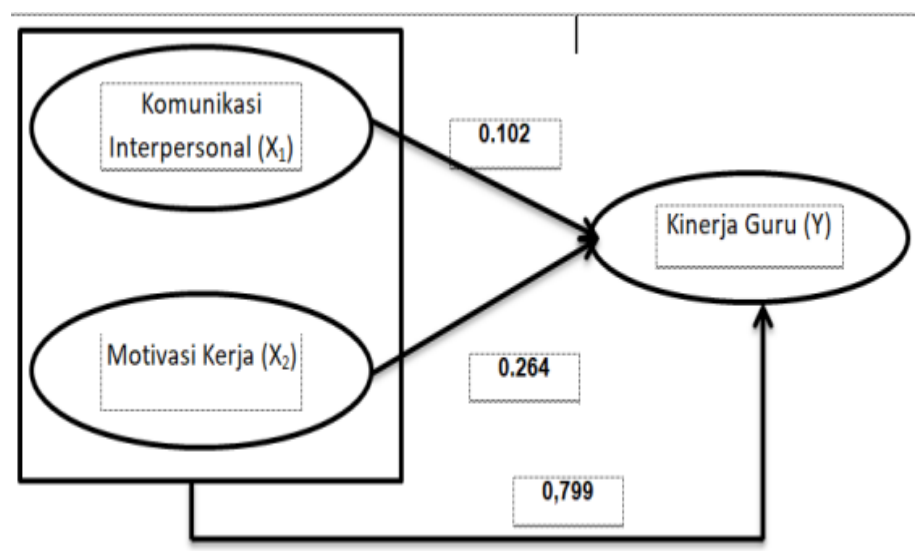


Gambar 2. Pengaruh Komunikasi Interpersonal (X1) dan Motivasi Kerja Guru (X2) Terhadap Kinerja Guru (Y)

Tabel 4. Pengaruh Komunikasi Interpersonal (X1) dan Motivasi Kerja Guru (X2) Terhadap Kinerja Guru (Y)

\begin{tabular}{cccc}
\hline Variabel & $\begin{array}{c}\text { Standar } \\
\text { Koefisien Beta }\end{array}$ & Pengaruh & Kesimpulan \\
\hline $\begin{array}{c}\text { Komunikasi } \\
\begin{array}{c}\text { Interpersonal } \\
(\mathrm{X} 1)\end{array}\end{array}$ & 0.302 & 0,102 & Signifikan \\
\hline $\begin{array}{c}\text { Motivasi Kerja } \\
(\mathrm{X} 2)\end{array}$ & 0.514 & 0,264 & Signifikan \\
\hline $\mathrm{R}^{2}=0,638$ (Simultan) & & & \\
\hline Sumber: Ouput SPSS &
\end{tabular}

Sumber : Ouput SPSS

Hipotesis dari penelitian ini adalah Komunikasi Interpersonal dan Motivasi Kerja berpengaruh terhadap Kinerja Guru baik secara simultan maupun secara parsial pada Guru SMA Negeri Se Kotamadya Pekanbaru. Hasil Penelitain Menunjukkan bahwa secara simultan maupun parsial Komunikasi Interpersonal dan Motivasi Kerja berpengaruh terhadap Kinerja Guru. Besarnya pengaruh Komunikasi Interpersonal dan Motivasi Kerja terhadap Kinerja Guru adalah 0,638, sedangkan sisanya sebesar 0,362 dipengaruhi oleh faktor lain yang tidak diteliti dipenelitian ini. Hasil penelitian ini sejalan dengan penelitian yang dilakukan oleh Rofijah (2017); Fitrina Afrianti (2015); Aleksius Madu (2017);

Pengaruh Komunikasi Interpersonal Terhadap Kinerja Guru SMA Negeri se Kota Pekanbaru

Hasil dari penelitian ini sejalani dengan pendapat yang disampaikan oleh Pace dan Faules (2006) menjelaskan bahwa komunikasi organisasi sebagai perantara antara sumber daya manusia dengan berfungsinya organisasi dan hasil organisasi, berupa vitalitas. Komunikasi yang terjadi di sekolah terutama antara kepala sekolah dan guru, jika dilakukan secara baik dan intensif, maka akan mempengaruhi sikap guru dalam menjalankan tugasnya sehari-hari, yang
Alice Tjandralila (2004) yang mengemukakan bahwa Kinerja Guru dipengaruhi oleh Komunikasi Interpersonal dan motivasi Kerja.

Sedangkan secara parsial pengaruh Komunikasi Interpersonal terhadap Kinerja Guru adalah sebesar 0,102 hasil penelitian ini sejalan dengan penelitian yang Fitri Afrianti (2015) mengemukakan bahwa Kinerja Guru dipengaruhi oleh Komunikasi Interpersonal.

Pengaruh Motivasi Kerja terhadap Kinerja guru adalah sebesar 0.264. Hasil Penelitian ini sejalan dengan penelitian Titin Eka Ardiana (2017).

berujung pada peningkatan kinerjanya di sekolah. Sebaliknya, apabila proses komunikasi yang terjadi di sekolah kurang baik, maka dapat menimbulkan sikap yang otoriter. Terutama ketika terjadi perbedaan pendapat yang berkepanjangan antara kepala sekolah dan guru. Jika hal itu terjadi, maka dapat berdampak pada kinerja guru yang kurang maksimal.

Pengaruh Motivasi Kerja terhadap Kinerja Guru SMA Negeri se Kota Pekanbaru 
Pengujian hipotesis menyimpulkan bahwa terdapat pengaruh yang signifikan antara motivasi kerja dengan kinerja guru SMA Negeri se Kotamadya Pekanbaru.

Hasil dari penelitian ini sesuai dengan pendapat yang disampaikan oleh Simamora dalam Mangkunegara (2005) menyatakan bahwa terdapat pengaruh antara motivasi kerja terhadap kinerja. Faktor yang mempengaruhi kinerja diantaranya yaitu motivasi kerja. Hal ini dilihat dari faktor-faktor yang mempengaruhi kinerja, diantaranya faktor psikologis, dalam faktor ini terdapat variabel motivasi kerja terhadap pekerjaannya sendiri.

Berdasarkan hasil penelitian Rahardja (2004) yang menerangkan bahwa motivasi kerja mempunyai pengaruh yang positif dan signifikan terhadap kinerja guru SMUK BPK Penabur Jakarta. Hasil penelitian Rahardja (2004) didukung oleh hasil penelitian Mustamil (2008) bahwa motivasi berpengaruh positif terhadap kinerja pegawai di kantor Departemen Agama Kabupaten Boyolali.

\section{Pengaruh Komunikasi Interpersonal dan Motivasi Kerja Guru secara simultan terhadap Kinerja Guru SMA Negeri se Kota Pekanbaru}

Kinerja sebagai hasil kerja secara kualitas dan kuantitas yang dicapai oleh seorang pegawai dalam melaksanakan tugasnya sesuai dengan tanggung jawab yang diberikan. Menurut Nova Gita (2018) salah satu faktor yang dapat mempengaruh Kinerja ialah Komunikasi Interpersonal. Hal ini sejalan dengan penelitian yang telah dilakukan oleh Burju Ruth (2017) yang menjelaskan bahwa terdapat pengaruh yang signifikan antara komunikasi Antar pribadi dengan kinerja guru di sekolah. Seperti yang telah dijelaskan sebelumnya bahwa salah satu variabel lainya yang mempengaruhi kinerja Guru adalah motivasi kerja. Menurut Uno (2012:71) motivasi kerja merupakan salah satu faktor yang turut serta menentukan kinerja seseorang dan merupakan suatu proses yang dilakukan untuk menggerakkan guru agar prilaku mereka dapat diarahkan pada upayaupaya yang nyata untuk mencapai tujuan yang telah ditetapkan. Penelitian yang telah dilakukan oleh Rofijah (2017) mengemukakan bahwa Komunikasi Interpersonal kepala sekolah dan motivasi kerja secara bersama-sama berpengaruh terhadap kinerja guru. Penelitian lainnya yang juga diyakini relevan adalah penelitian yang dilakukan oleh Fitrina Afrianti (2013) bahwa variabel motivasi kerja dan komunikasi interpersonal secara simultan berpengaruh signifikan terhadap kinerja guru pada SMA Negeri 6 Kerinci Kecamatan Danau Kerinci

\section{H. KESIMPULAN DAN SARAN 1. Kesimpulan}

Dari hasil penelitian diperoleh simpulan yaitu, Komunikasi interpersonal dan motivasi kerja guru berpengaruh secara simultan maupun parsial terhadap Kinerja Guru.

\section{Saran}

a. Hasil penelitian menunjukkan bahwa variabel komunikasi interpersonal dan motivasi kerja memiliki peranan yang menentukan dalam meningkatkan kinerja guru SMA Negeri se Kota Pekanbaru. Untuk itu disarankan agar guru selalu membangun komunikasi yang baik terhadap sesama guru, siswa maupun pimpinan sekolah.

b. Kepala sekolah sebagai pimpinan disarankan untuk selalu membangun komunikasi yang baik dengan para bawahannya serta memberi teladan tentang 
disiplin sehingga guru termotivasi dalam bekerja sehingga kinerja guru akan optimal.

\section{DAFTAR PUSTAKA}

Alice Tjandralila Raharja. (2014). Hubungan Antara Komunikasi Antar Pribadi Guru dan Motivasi Kerja Guru SMUK BPK PENABUR Jakarta. Jurnal Pendidikan Penabur. Vol.3, No.3

Anwar Prabu Mangkunegara. (2007). Evaluasi Kinerja Sumber Daya Manusia Edisi Revisi 9. Jakarta: PT. Bumi Aksara.

Arni Muhammad. (2014). Komunikasi Organisasi. Jakarta : PT. Bumi Aksara

Daryanto. (2012). Ilmu Komunikasi 1, edisi revisi. Bandung : Satu Nusa

Fitrina Afrianti. (2015). Pengaruh Motivasi Kerja Dan Komunikasi Interpersonal Terhadap Kinerja Guru Pada SMA N 6 Kerinci Kecamatan Danau Kerinci. Vol 1 No 22015

Hesti Murwati. (2013). Pengaruh Sertifikasi Profesi Guru Terhadap Motivasi Kerja dan Kinerja Guru di SMK Negeri se-Surakarta. Jurnal Pendidikan Bisnis dan Ekonomi (BISE) Vol.1, No.1.

Madu Aleksius. (2013). Hubungan Kepemimpinan Kepala Sekolah dan Komunikasi Interpersonal dengan Motivasi Guru Matematika SMA. Jurnal Pendidikan Matematika. Vol 8 No.1 (12-20). ISSN :1978-4538
Muhibbin Syah. (2013). Psikologi pendidikan dengan Pendekatan Baru. Bandung : PT Remaja Rosdakarya

Mulyasa. (2017). Uji Kompetensi dan Penilaian Kinerja Guru. Bandung : PT Remaja Rosdakarya Offset

Mustamil, (2008), "Pengaruh Motivasi Kerja, Kepemimpinan dan Lingkungan Kerja terhadap Kinerja Pegawai Kantor Departemen Agama Kabupaten Boyolali", Tesis: Program Studi Magister Manajemen, Program Pas-ca Sarjana. Universitas Slamet Riyadi, Surakarta.

Nofrion. (2018). Komunikasi Pendidikan, Penerapan Teori dan konsep Komunikasi dalam Pembelajaran Edisi pertama. Jakarta : Prenadamedia Group

Oemar Hamalik. (2003). Proses Belajar Mengajar. Bandung: Bumi Aksara

Peraturan Pemerintah Nomor 19 Tahun 2005. Tentang Sistem Pendidikan Nasional Indonesia.

Peraturan Pemerintah Republik Indonesia Nomor 74 Tahun 2008 Tentang Guru

Pandi Afandi. (2018). Manajemen Sumber Daya Manusia. Riau : Zanafa Publishing

Robins, Stephan P. (2015). Prilaku Organisasi.Jakarta : Salemba Empat

Rojifah Dinul Maula. (2017). Pengaruh Komunikasi Interpersonal Kepala Sekolah Dan Motivasi Kerja 
Terhadap Kinerja Guru Di Smp Swasta Se-Kecamatan Tandes. Jurnal Manajemen Pendidikan, Kota Surabaya. Volume 4 Nomor 1

Sardiman. (2012). Interaksi Motivasi Belajar Mengajar. Jakarta: PT Raja Grafindo Persada

Sedarmayanti. (2007). Manajemen Sumber Daya Manusia Reformasi Birokrasi dan Manajemen Pegawai Negeri Sipil. PT Refika Aditama : Bandung

Sri Rahayu. (2017). Komunikasi Interpersonal Kepemimpinan Kepala Sekolah dan Budaya Organisasi Terhadap Motivasi Kerja dan Dampaknya pada Kepuasan Kerja Guru Sekolah Menengah Pertama. Jurnal Manajemen Pendidikan. Vol 12, No 1. 2-ISSN : 2548-6780

Sopiah. Perilaku Organisasi. (2008). Yogyakarta: ANDI

Sudarto, dkk. (2009). "Pengaruh Komunikasi Interpersonal dan Motivasi terhadap Kinerja Karyawan PT. Westfalia Indonesia". Jurnal Keungan dan Bisnis. Volume 1 Nomor 2.
Peraturan Pemerintah Republik Indonesia Nomor 74 Tahun 2008 Tentang Guru

Supardi. (2014). Kinerja Guru. Jakarta : PT. Raja Grafindo Persada.

Titin Eka Ardiana. (2017). Pengaruh Motivasi Kerja Guru Terhadap Kinerja Guru Akuntansi SMK Di Kota Madiun. Jurnal Akuntansi Dan Pajak. Vol 17, No 12 Januari $2017-14$.

Undang - undang Nomor 20 Tahun 2003 Bab II Pasal 3 tentang Sistem Pendidikan Nasional.

Undang-Undang Nomor 14 tahun 2005 Tentang Guru dan Dosen

Uno B. Hamzah. (2013). Teori Motivasi dan Pengukurannya Analisis di Bidang Pendidikan. Jakarta : Bumi Aksara

Wibowo. (2013). Manajemen Kinerja Edisi ke-5. Jakarta : Rajawali Pers

Siti Hidayah dan Kukuh Pribadi. (2015). Jurnal ekonomi manajemen Volume 18 No 31 Oktober 2011 